\title{
SMST Announces \$50,000 Award for Graduate Students Doing Research on Nitinol
}

(c) ASM International 2016

The International Organization on Shape Memory \& Superelastic Technologies (SMST), an affiliate society of ASM International, is seeking applications for the 2017 SMST Fellowship. The intent of the SMST Fellowship is to provide a current use gift to a deserving graduate student(s) with the purpose of initiating interest in a unique path of research for shape memory materials such as Nitinol. The award, which is financially supported in 2017 by Edwards Lifesciences, includes a stipend up to $\$ 50,000$. Deadline to apply is January 9, 2017. To learn more visit http://www.asminternational.org/web/smst/newswire/-/jour nal_content/56/10180/26606312/NEWS. 